УДК 821.16-1::78.02 Пушкин, Александар Сергејевич https://doi.org/10.18485/msc50_vuk_trsic.2021.ch30

Вера Бојић

\title{
ПУШКИНОВЕ ПЕСМЕ ЗАПАДНИХ СЛОВЕНА КОД РУСКИХ КОМПОЗИТОРА
}

(Један пример литерарне и музичке рецепције српских народних песама)

О Пушкиновим Песмама Западних Словена постоји обимна литература, посебно о њиховим изворима и генези, о одступањима од оригинала и естетско-формалним карактеристикама циклуса у целини. ${ }^{1}$ Као што је познато, песме су објављене 1835. а настале су по мишљењу Томашевског, у времену између 1828. и 1834. године. Констатовано је да је једанаест од укупно шеснаест песама циклуса Пушкин преузео из мистификације Проспера Меримеа објављене 1827. под насловом La Guzla; две песме су идентификоване у Вуковим збиркама, и то: Соловей (код Вука Три највеће туге под бр. 542 у І књизи) и Сестра и братья (код Вука Бог ником дужан не остаје под бр. 5 у II књизи); за преостале три песме (Песнь о Георгии Черном, Воевода Милош и Јаныи королевич) извор није утврђен, а Томашевски претпоставља да би могле бити Пушкинове сопствене ${ }^{2}$.

Посматрано са аспекта литерарне рецепције ово дело садржи, дакле, три слоја која упућују на различите изворе. Стога се, као прво, намећу следећа питања: шта се из Песама Западних Словена да закључити о аутору и читаоцу као инстанцама унутар текста, и као реалним датостима у конкретном историјском контексту? Које место заузима ово дело у оквиру литерарне рецепције српских народних песама у свету?

1 Упућивања у овом тексту односе се на следеће радове: Н. И. Кравцов, Србскохорватскй эпос, Москва, 1985. В. Недић, Прва Карачићева књига Српских народних пјесама, Српске народне пјесме I (Сабрана дела Вука Караџића 4), Београд, 1975, 627-665. Б. В. Томашевский, Генезис „Песен Западных Славян”. О стихе, Минхен, 1970, 77-93. Исти: О стихе „Песен Западных Славян”, нав. дело, 63-76. Исти: Пушкин II (1824-1837), Москва-Лењинград, 1961.

2 Пушкин II, 278. 
Међутим, рецепцију књижевности - посебно народне поезије - треба изучавати и изван подручја литературе, јер се управо у прекорачивању тих граница најбоље сагледава домет утицаја једног књижевног дела. На пример: Песме Западних Словена инспирисале су повелики број руских композитора, а то, између осталог, указује и на популарност овог дела код читалачке публике. С друге стране, настанком музичких композиција остварио се још један вид рецепције српских народних песама у облику симбиозе двеју уметности - поезије и музике. С обзиром на те чињенице треба, као друго, размотрити питање узајамног односа Пушкиновог текста и музике као и везе ове последње са српским народним мелосом.

1. Пушкин као аутор Песама Западних Словена показује се истовремено као реципијент - и то у много већој мери него што је то и иначе сваки аутор - али као креативни реципијент-продуцент. Бројна, у науци већ утврђена одступања од изворника, као и с правом истицана садржајно-формална оригиналност циклуса довољан су разлог да ове песме не треба посматрати као преводе, јер превођење очигледно није ни било Пушкинов циљ. О односу Пушкина-реципијента према српским народним песмама најречитије говори избор који је он направио из споменутих извора. Наиме, према двема песмама из Вукових збирки стоји једанаест из Гусле, што недвосмислено показује да су Пушкина више привлачиле Меримеове песме него српске народне. Излишно је притом постављати питање да ли би се он користио Меримеовим мистификацијама да је знао истину, јер ју је, без сумње, знао и одобравао 3 . Објашњење горње чињенице треба тражити у типолошкој сродности између ове двојице аутора, која се одражава како у њиховој поетици тако и у стваралачком поступку.

За Пушкина је - као и за Меримеа - фолклорна изворност била од секундарног значаја у односу на поетску вредност. Његов однос према народној поезији - иако ју је записивао чак и са издавачким намерама првенствено је песнички, без научно-филолошких стега. Тако су могле настати његове слободне обраде разних народних умотворина, чије је интернационалне изворе наука тек касније утврдила. А мистификације, које су у то доба имале већ дубоку традицију, биле су за Пушкина, очи-

${ }^{3}$ Из 18. нап. уз Песме јасно се види шта је за Пушкина у Гусли најбитније: саопштавајући и читаоцима своју сумњу да је Хиацинт Маглановић икада постојао, његову биографију из Меримеовог пера прештампава да би публика уживала у њој, јер поседује „лепоту оригиналности и уверљивости”. 
гледно, један од легитимних видова песничког поступка ${ }^{4}$ То најбоље доказују његове три песме у циклусу, испеване у истом духу као и Меримеове, а посебно она, наизглед чешка, о Јаношу Краљевићу, у којој се, заједно са српском вилом, појављују и ликови из мистификације Вацлава Ханке. Тај шаролики, фиктивни свет Песама Западних Словена обједињује непознати народни певач, на којег Пушкин упућује насловом свог циклуса, а он - иако је остао без имена и биографије - има исту функцију као и Меримеов Хиацинт Маглановић. Из приложеног произилази следећи закључак: признајући Пушкиновом циклусу оригиналност, а посматрајући га у оквиру рецепције српских народних песама, стављамо га у исти ред са Меримеовим мистификацијама. Притом је потребно истаћи да су мистификације један од креативних видова рецепције; њихова естетска вредност је зависна од уметничке снаге дотичног песника, а она, у случају Меримеа и Пушкина, стоји ван сваке сумње.

Осим наведених поетолошких компонената типолошка сродност између обојице аутора уочљива је и са аспекта естетике стваралачког чина. Обојица су читали да би писали, у оба дела је директна веза са лектиром непобитна. Међутим, у односу аутора према интенционалном читаоцу постоји суштинска разлика. Мериме је, свесно следећи свој мистификаторски циљ, истраживао очекивања реалне читалачке публике - а Пушкин је следио сопствене литерарне наклоности, које су, као што је познато, биле интензивно управљене према француској књижевности. „Гусла” је изванредан пример теорије о утицају читаоца на аутора: ауторов интенционални читалац се у овом случају подударио са реалним, а резултат је био велики успех овог дела ${ }^{5}$. Али са аспекта литерарне комуникације десио се један од оних чувених „неспоразума”: Мериме је желео да се подсмехне романтичарској занесености „локалним колоритом”, а читаоци су управо њиме били одушевљени.

За разлику од Меримеовог Пушкиново дело у прво време није имало великог одјека код Руса ${ }^{6}$. У размишљању о разлозима намеће се поређење Песама са Гуслом, а из њега произилазе, као најупадљивије, следеће разлике: Пушкин је Меримеов „локални колорит” углавном одстранио, и то:

4 Његову изјаву да се нашао у отменом друштву преварених (са Мицкијевичем), треба схватити као саставни део игре са читаоцем. Кравиов, 68, наводи да се у руским часописима већ од 1828. писало о Гусли као мистификацији, што је Пушкину морало бити познато.

5 Превођено је и на немачки (В. Герхард) и на енглески (Џ. Бауринг).

6 Томашевски, Пушкин II, 437, наводи да су Песме остале скоро непримећене у руској јавности, изузимајући двојицу великана, Толстоја и Достојевског; последњи их је назвао ремек-делом у Пушкиновом стваралаштву. 
избором текстова, прерадама и скраћивањем или избацивањем лирских описа. Од песама у прози створио је баладе, концентрисањем драмских елемената око главних јунака - појединаца, који су или племенити злочинци бајроновског типа (такав је и његов Карађорђе, који у име виших идеала слободе српског народа постаје оцеубица), или пате због људске пакости и злобе (у ту тематику изванредно се уклапа и извор Вукове песме Бог ником дужен не остаје), или су жртве натприродних сила, вампира (ту тему је Пушкин у песми Вурдлак обрадио са њему својственом иронијом). Запажено је да је уносио српска имена, а осим тога и језичке турцизме, које је морао објашњавати у напоменама, што сигурно није доприносило читкости текста: циљ му је, вероватно, био да и сам постигне известан локални колорит. Али Пушкин није испунио очекивања својих реалних читалаца. Разлози за то су, као и у другим аналогним случајевима, комплексни и тешко објашњиви. Па ипак, можда би следећа питања била вредна размишљања: да ли је Пушкин у овом свом делу, с обзиром на наведене типолошке сродности са Меримеом, стајао ближе француским литерарним нормама и укусу него рускима? Да ли је на руске читаоце могло утицати обелодањивање истине о Меримеовој „превари” на коју је Пушкин, наводно, „насео”? Ако јесте, онда би то био један конкретан податак о разлици између општеприхваћених литерарних норми код Руса и Француза. Француским читаоцима Меримеова мистификаторска игра очигледно није умањивала естетско уживање - судећи и по томе што је Гусла 1840. године доживела друго, проширено издање. Пушкинове Песме су код Руса, изгледа, најинтензивније реципиране у периоду од седамдесетих година прошлог до друге деценије овог века, јер су у то време настајале композиције на њихове текстове.

Од свих песама циклуса „Славуј” је најчешће инспирисао композиторе. Зато би, у оквиру овог излагања, он могао послужити као пример литерарне и музичке рецепције српских народних песама. У ту сврху неопходно је, као прво, упоредити Пушкинов текст са Вуковим оригиналом.

Три највеће туге.

Славуј птица мала сваком покоі дала.

А мени јунаку три туге задала: ${ }^{7}$

Прва ми је туга на срдашцу моме,

Што ме није мајка оженила млада;

\section{СОЛОВЕЙ}

Соловёи мой, соловёйко, Птйца мйлая лесная! У тебя яь, у малой птицы, Незаменные три песни,

${ }^{7}$ Мјесто ове прве двије врсте једни пјевају и овако:

Мрак на земљу паде, сваком покој даде,

А мени јунаку три туге зададе. 
Друга ми је туга на срдашцу моме,

Што мој вранац коњиц пода мном не игра; Трећа ми је туга, ах! На срцу моме, Што се моја драга на ме расрдила. Копајте ми раку у пољу широку, Два копља широку, четири дугачку; Више моје главе ружу усадите, Сниже моји ногу воду изведите: Које младо прође, нек се ружом кити, Које л’ старо прође, нека жеђу гаси.
У меня ли, у молодца,

Три великие заботы! Как уж первая забота Рано молодца женйли; А вторая-то забота Ворон конь мой притомился; Как уж третья-то забота Красну девицу со мною Разлучили злые люди. Вы копайте мне могилу Во поле, поле широком, В головах мне посадите Алы светики-цветочки, А в ногах мне проведите Чисту воду ключевую. Пройдут мимо красны девки, Так слетут себе веночки. Пойдут мимо стары люди, Так воды себе зачерпнут.

Beћ на први поглед пада у очи различита дужина песама и стихова. Према Вуковој од четрнаест стихова стоји Пушкинова од 23 стиха, а разлог томе није разлагање оригиналног дванаестерца на краће стихове, као што је то учинила Талфај у свом, иначе дословном преоводу. Разлози се налазе у проширењу садржајних компонената. Оригинал почиње супротстављањем умилне песме славуја психичком стању лирског субјекта; антитеза је смештена у прва два стиха, а славуј, окарактерисан тзв. „сталним” епитетом, спомиње се само у првом стиху, његова улога се ограничава на стварање лирске атмосфере, грађене на контрасту између мира природе са неометаном песмом птице, и немира младићевог, чије се највеће три туге затим наводе. Славујева функција у песми је маргинална и заменљива, као што Вук и наводи у напомени испод текста. Наспрам ова два стиха стоји код Пушкина шест. У њима је антитетска структура оригинала замењена паралелизмима сличности између славуја и лирског субјекта (У тебя ль, у малой птицы - У меня ли, у молодца), између славујеве три песме и младићеве три туге Незаменные три песни - Три великие заботы). Разрађеност те теме у првих шест стихова, а посебно сам наслов песме, преносе славуја са маргиналија оригинала у средиште Пушкинове песме, чиме се она највише удаљује од Вукове народне; текст ту постаје вишезначан, отворен за различите интерпретације. С једне стране, наведени паралелилизми повезују и поистовећују славуја и лирски субјект - у Пушкиновој поезији славуј се често јавља 
као метафора за песника пр., у Соловей и роза, Соловей и кукушка - а с друге стране, апострофа птице их раздваја, истовремена присутност обе стилске компоненте ствара подвојеност лирског субјекта, карактеристичну посебно за поезију романтизма. А она је спроведена и у даљем Пушкиновом тексту на онима местима где он одступа од оригинала. У српској народној песми младићеве три туге стоје у каузалном односу: није се оженио па му се драга расрдила, а испод невеселог јахача ни коњ не игра. Пушкинов младић стоји у конфликту између несрећног брака, у који су га увукли младог, и неостварене љубави према недостижној драгој, с којом су га раставили зли људи - а такав конфликт није тема карактеристична за српску народну поезију. Међутим, Пушкин сигурно није погрешно разумео оригинал, идеју за то одступање је, вероватно, добио из руских народних песама са таквом темом, чије записе је поседовао ${ }^{8}$. И крај Пушкинове песме се разликује од Вукове, и то проширивањем слике младићевог гроба у веселу сцену са изворском водом, црвеним цветовима и девојкама, које од њих плету венце. Употребљени језички материјал и промењени, убрзани и скоро весели ритам стварају контраст према претходном тексту, релативирајући значај индивидуалне патње и смрти у контексту веселог протицања живота.

Метрика и ритам Пушкиновог стиха у Славују представљају изузетак у целом циклусу те су, вероватно, због тога остали по страни у разматрањима о тој теми. Сматра се да је Пушкин у Песмама Западних Словена, углавном, следио метричку шему коју је поставио Востоков са својим преводима, а она се заснива на варијацији српског десетерца као петостопног трохеја; та руска варијанта садржи три акцента са варијабилним распоредом ненаглашених слогова, дактилском или трохејском каденцом и, по могућству, цезуром после четвртог слога. Томашевски је утврдио Пушкинова одступања од тог узора, посебно у вези са цезуром и бројем слогова, објашњавајући последње, тј. неправилан број слогова и разликом између дуге придевске форме књижевног језика и њене краће, изговорне варијанте од које је Пушкин полазио 9 Међутим, пет од шеснаест песама циклуса испевано је краћим стихом од седам до осам слогова, а међу њима стих Славуја заузима посебно место са следећим особинама: доминантном женском каденцом, и то

8 Генезис Томашевски, нав. дело, 85-86, наводи две песме у којима су и ови стихови: „Недораслем меня бедного женили.” „Стал молодцем, жена стала старенька. / Полюбилась мне молодка молодая."

9 Томашевски, O стихе, нав. дело, 71; али то се не би могло применити на Славују. 
вокалном (изузев у 15. и 23. стиху), а то је особина и српске народне поезије; у осталим песмама испољава се Пушкинова склоност према мушкој каденци и јамбу. Затим, доследно остварена дужина стиха од осам слогова, а у вези с њом стоји и паралелна употреба дугих и кратких придевских облика, што наводи на закључак да се Пушкин у овој песми свесно придржавао те силабичне компоненте српске метрике. Ненаглашени слогови су распоређени између два или три, а у последњим стиховима четири акцента, од којих су два редовно на трећем и седмом, а остали, углавном, на првом или петом слогу, дакле, на непарним слоговима као и у српској народној поезији. Али и поред наведених елемената подударања песма „Славуј” је неупоредиво ближа руским него српским народним песмама, а та блискост почива, пре свега, на језику, тј. стилским средствима руске народне поезије као, нпр.: етимолошкој фигури (соловей - соловейко, цветики - цветочки) сталним епитетима, кратким придевским формама. Примена тих стилских средстава показује мајсторство великог песника: тко, нпр., споменути кратки придевски облици, карактеристични за народну поезију, сконцентрисани су у последњим стиховима омогућавајући остварења четири акцента, а тиме и убрзани ритам у контексту конкретног пролажења поред гроба, које истовремено асоцира са пролазношћу живота. Семантички релевантном показује се и паралелна употреба речи „девка” (девојка из неповлашћеног, нижег слоја) поред народне „девица”, а посебно је језички креативан четврти стих, у којем се, као што је већ наведено, Пушкин највише удаљио од оригинала: славујеве три песме „произвеле” су реч „незаменные” (уместо „незаменимые”), коју је песник употребио само овде, а ушла је у Академијин речник са њим као извором. Осим наведених особина ова песма се удаљује од оригинала и одсуством константне цезуре као битног елемента српске версификације.

Из претходне анализе може се извести следећи закључак: Славуј није, ни садржајно ни формално, еквивалентан превод српске народне песме Три највеће туге, већ је обрада њених мотива, који су у структури Пушкинове песме добили ново значење. Притом треба напоменути да Славуј спада међу оне песме циклуса у којима је веза са оригиналом најбоље очувана; и у њима се, дакле, Пушкин показује као продуктивни реципијент, а не као преводилац.

2. Песме Западних Словена прихваћене су, као што је већ споменуто, и у области руске музике. Петорица композоритора одабрали су те Пушкинове текстове да на основу њих компонују своје мелодије: Борис Шељ 1879. године, Петар Чајковски 1886, Николај Компанејски 1911. Цезар 
Кјуи 1916. и Николај Метнер $1916^{10}$. поред славног Чајковског, и Кјуи и Метнер су значајна имена у руској музици, док су Шељ и Компанејски данас познати само историчарима музике.

Настанком ових композиција поново се остварила симбиоза поетског текста и музике - поново, јер народна песма у својој суштини представља такву симбиозу: текст и мелодија су настајали упоредо, узајамно се одређујући ${ }^{11}$. Вук је скупио и издао само текстове (изузев шест записа мелодија од Ф. Мирецког), текстови су превођени, и изучавање рецепције наше народне поезије ограничило се на подручје литературе. Међутим, велики број композиција, које су на основу тих превода настале широм света $^{12}$, указује на неопходност истраживања и музичке (а вероватно и ликовне) уметности. Научни приступ поетско-музичкој симбиози намеће бројне методолошке проблеме, јер се, по речима Ulriha Wajsštajna ${ }^{13}$, ради о оном граничном појасу, или ничијој земљи, у коју с времена на време продиру са разних страна научници-номади, полажући право на њу сваки са свога аспекта. Па ипак, између тих номада постоји консензус о томе да је изучавање додира између поезије и музике задатак литерарне компаратистике, док би музика per se остала у домену музикологије.

Додире између поезије и музике, који су уочљиви кроз целу историју, Калвин Браун ${ }^{14}$ је је свео, као апстракцију, под четири главне категорије, које се у пракси вишеструко укрштају, а то су:

10 Засада су ми познати само наведени композитори, али није искључено да их има и више. - Соловей. Музыка Бориса Шеля. Слова. А. Пушкина. Романсы и песни. Спб. У Бернарда, 1879; П. И. Чајковский, Соловей. Двенадцать романсов ор. 60, Москва, 1886 (Юргенсон); Соловей. Слова А. Пушкина. Музыка Н. Компанейского. Изд. П. Юргенсона. Москва, 1911; 6 песен западных славян. Слова А. С. Пушкина. Музыка Ц. Кюи. Изд. М. П. Беляева. Пгр. 1916: Похоранная песня (Песни западных славян). Музыка Н. Матнера. (6 стихотворений Пушкина для пения и фортепиано). Изд. Россиск, музыкального изд-ва. Москва (1916).

11 С тим у вези би било занимљиво питање: колико су одређени мелодијски обрасци, укључујући и византијске, могли утицати на развој версификације наше народне поезије?

1285 композиција од 21 аутора објављене су у књизи В. Бојић, Вуково наслеђе y европској музиии. Vuks musikalische Erben. Београд/Минхен, 1987 - а оне су, вероватно тек један део тог досада сакривеног блага.

13 Ulrich Weisstein, Die wechselseitige Erhellung von Literatur und Musik: Ein Arbeitsgebiet der Komparatistik?, Literatur und Musik: e. Handbuch zur Theorie und Praxis e. Komparatist Granzgebietes, hrsg. V. Steven P. Scher, Berlin, 1984.

${ }^{14}$ Calvin S. Brown, Theoretische Grundlagen zum Studium der Wechselverhältnisse zwischen Literatur und Musik. Literatur und Musik, (в. нап. 12), 28-39. 
- $\quad$ комбинација обе уметности, остварена у вокалној музици, пре свега у песми;

- $\quad$ замена, тј. покушај једне уметности да заузме место друге (пример: опонашање музике на једној - програмска музика на другој страни, и сл.);

- $\quad$ утицај једне уметности на другу (нпр. музичког лајтмотива на унутрашњи монолог и сл. - или поетских тема у музици, нпр. Листовим симфонијама Фауст и Данте, и сл.);

- $\quad$ паралеле и аналогије које постоје између тих двеју уметности као естетских структура.

Управо су паралеле и аналогије она основа на којој почивају могућности додира између обеју уметности. Например, обе уметности - за које се сматра да имају заједничко порекло - користе звук као медијум експресије; упркос чињеници да постоји битна разлика између музичког тона и језичког гласа, као уосталом и између музичког и језичког система знакова, на тој аналогији заснивала се тежња поезије романтизма и, још више, симболизма да се приближе музици као највишој уметности.

Најважнији и најпродуктивнији облик додира двеју уметности је „комбинација”. Притом треба напоменути да у тој синтези узајамни однос поезије и музике кроз историју није био увек исти. Ако је певағе првобитно било стваралачки чин у ком су настајале обе уметности, касније је дошло до њиховог раздвајања најизраженијег у тзв. апсолутној музици, али и у вокалној када је текст служио само као носилац мелодије (нпр. у коралима, и сл.). Тај развојни процес није у суштини погодио народну песму, у њој се, углавном, сачувала првобитна симбиоза обе уметности. Али и уметничка вокална музика епохе о којој је овде реч, полезећи од текста тежи за таквом симбиозом - заокрет у начину поступања са текстом кулминирао је у покушајима стварања јединственог уметничког дела (нпр. у Вагнеровим операма).

У истраживањима односа између музике и текста утврђено је да постоје поетски текстови који поседују „музички афинитет” јер су изразито привлачни за композиторе. Ту на прво место долази лирика. Лирика je, као што је познато, онај књижевни род који се у највећој мери удаљује од нормалне употребе језика потискујући његову рационалну компоненту у корист афективне (емоционалне), приближавајући га, у мањој или већој мери, чистој форми, а одсуство значења изван форме, тј. форма као значење само по себи карактеристика је музичке уметности. У лирици је, значи, аналогија између двеју уметности најизраженија. Композиторе 19. века посебно је привлачила народна лирска песма, као и уметничка 
песма у народном духу, а разлози томе су: с једне стране утицај идеја романтизма и у области музике, а с друге „музикалност” тј. организација језика тих текстова која произилази из њихове првобитне симбиозе са мелодијом, тј. из чињенице да су стварани да би били певани.

Међутим, није само тзв. музикалност песничког језика оно што привлачи композиторе. То потврђује велики број композиција које су настале на основу текстова немачког писца Хајнриха фон Клајста. Наиме, његов стил су неки ранији критичари окарактерисали као лош, а језик местимично чак и као погрешан, не схватајући да су синтаксичка разбијеност и недовршеност Клајстове реченице најбоља форма израза неизрецивости душевних и емоционалних стања његових личности, као и недоречености садржаја у његовим делима. Истраживања музичког афинитета Клајстових дела довела су до закључка да је управо у тој недоречености музика нашла простора да својим средствима, ослобођеним језичке рационалности, комплементира исказ уметничког дела ${ }^{15}$. Насупрот томе, једна формално савршена и мисаоно завршена песма, као нпр. она Гетеова Über allen Gipfeln ist Ruh, по мишљењу Алберта Велека, не оставља простора музици, која се ту показује као сувишан додатак композитори такве песме или избегавају, или не створе „врхунску” музику ${ }^{16}$.

Пушкин је као ретко који песник, ништа мање а можда чак и више него Гете, привлачио композиторе, и то не само руске. Зато не изненађује чињеница да су се и његове Песме Западних Словена више пута појавиле и као поетско-музичка симбиоза. Упадљиво је да су најмање тројица од наведених пет композитора ${ }^{17}$ одабрала и текст Славуја. Музички афинитет ове песме произилази по мом мишљењу из следећег: метричка правилност и богато остварени вокализам приближавају Пушкинов песнички језик музици у толикој мери да се овај текст скоро пева и при читању, а блискост руској народној песми већ сама по себи сугерира присуство мелодије. Затим, наведеним одступањима од семантике оригинала Пушкин је унео више недоречености и многозначности, које композиторима дају подстицаја и простора за надградњу. Музички израз у којем су се инспирације Славујем оствариле, стоји у зависности од стила самог композитора као и дотичне епохе, те се мора разматрати у сваком

15 Уп. О томе Detlef Müller-Hennig, Vom Musikalischen der Kleistschen Dichtung. Literatur und Musik, (в. нап. 12), 312-325.

${ }^{16}$ Albert Wellek, Über das Verhältnis von Musik und Poesie. Literatur und Musik (в. нап. 12), 71-83.

${ }_{17}$ Нису ми, на жалост биле доступне све партитуре, а из наслова неких дела̂ се не види да ли садрже и Славуја. 
појединачном случају. Два питања су, притом, релевантна у оквиру овде постављене теме: $п р в о$, да ли и шта текст и музика доприносе узајамном расветљавању? Друго, да ли је у музици сачувана веза са српским народним мелосом, који је, заједно са текстом, саставни део оригинала српске народне песме. Одговор на тај питања покушала бих да дам на примеру композиције Славуја Петра Чајковског.

Прво што у овој композицији Чајковског пада у очи су елементи мелодија руских народних песама. Горња анализа је показала блискост Пушкиновог текста руској народној поезији, и особине на којима се она заснива. Пушкиновог Славуја руски читалац је, очигледно, прихватао као руску народну или у народном духу испевану песму. То је усмерило и Чајковског у правцу руског народног мелоса, а то је утолико упадљивије што остале песме у истом опусу „[...] представљају 'романсе' не само у смислу руске терминологије (у којој тај израз значи соло-песму уопште), већ и у популарном смислу те речи, који подразумева известан призвук сентименталног и салонског [...]"18. Чајковски је стихове груписао у три строфе следећи при том трочланост у структури текста, која је произашла из Пушкиновог проширења садржаја оригинала: 1. славуј са своје три песме, 2. младићеве три туге, 3. сцена на гробу. „А у уводу, који наговештава главну тематску идеју, и у кратким интерлудијима дискретно се проткива фигура која асоцијацијом на птичји пев или звук фруле доприноси пасторалној, али меланхолијом засенченој оштрој атмосфери"19. Управо се понављањем те фигуре сугерише присуство славуја кроз целу песму, а то је, као једну могућност, и Пушкин уградио у свој текст поистовећујући славуја са лирским субјектом и дајући му три песме према трима тугама младићевим. Значи, оно што је у тексту било само наговештено, дошло је до јаснијег изражаја у музици Чајковског, која на тај начин доприноси и дубљем поимању Пушкинове песме. Дакле, у овом случају се поезија и музика узајамно расветљавају. Међутим, док је у Пушкиновом тексту, и поред стилских особина руске народне поезије, веза са српском народном песмом Три највеће туге непобитна, а произилази из семантике језика - та веза у музици Чајковског, која се ослања на руски, а не српски народни мелос, престаје да постоји.

* Рад је претходно објављен у зборнику Научни састанак слависта у Вукове дане, 17/5, 237-247.

${ }_{18}$ Властимир Перичић, Композииије на текстове из Вукове збирке. В. Бојић, Вуково наслеђе (в. нап. 11), 58.

${ }_{19}$ Нав. дело, 58. 